\title{
Determination of deoxynivalenol in feed, feed raw materials and food
}

\author{
(C) Nailya N. Mishina, ${ }^{+}$Ivan N. Shtyrov, Zukhra H. Sagdeeva, \\ Ramziya M. Potekhina, Oksana V. Shlyamina, and Eduard I. Semyonov \\ FSBSI «Federal Center for Toxicological, Radiation and Biological Safety » (FSBSI «FCTRBS-RRVI»). \\ Nauchnyi Gorodok-2. Kazan, 420075. Republic of Tatarstan. Russia. E-mail: mishinanailyan@yandex.ru
}

\begin{abstract}
*Supervising author; ${ }^{+}$Corresponding author
Keywords: mycotoxins, mycotoxicoses, deoxynivalenol, fusariotoxins, precision research.
\end{abstract}

Abstract
The article presents the survey data of 1830 average samples of feed, feed raw materials and food products received through the Test Center of the FSBSI «FCTRBS-RRVI»", provided by livestock and feed enterprises, agricultural companies, food manufacturers and 152 samples of feed provided by specialists of veterinary services, livestock enterprises, owners of peasant farms to determine the death of animals and birds, for the content of mycotoxin deoxynivalenol (DON) in the period from 2018 to 2020.

Determination of the DON content in the samples was carried out according to a certified procedure based on the method of thin layer chromatography.

In the course of summarizing the results, it was found that samples of feed, feed raw materials and food products received through the Test Center of the of the FSBSI «FCTRBS-RRVI» from different regions of the Russian Federation in terms of DON content corresponded to the normative indicators specified in the current regulatory and technical documentation.

When determining the cause of death of animals and birds, 152 samples were examined, received from farms of different regions of the Republics of Tatarstan, Bashkortostan, Mordovia, Kostroma and Ryazan regions. It was found that $1.97 \%$ of samples were contaminated with DON at concentrations from 0.2 to $0.5 \mathrm{mg} / \mathrm{kg}$ of feed, in the rest, the content of mycotoxin was below the sensitivity of the method $(<0.2 \mathrm{mg} / \mathrm{kg})$, which does not exceed the limit permissible concentration. It was recommended to exclude feed contaminated with mycotoxin from the diet of animals, since at the established concentrations, DON is not the main etiological factor in the death of animals, but due to the presence of carcinogenic, mutagenic, teratogenic, embryotoxic and immunosuppressive properties, together with other factors, it is contributing.

\section{References}

[1] J.C. Frisvad, U. Thrane, R.A. Samson, J.I. Pitt. Important mycotoxins and the fungi which produce them. Adv Exp Med Biol. 2006. Vol.571. P.3-31. doi: 10.1007/0-387-28391-9_1. PMID: 16408591.

[2] H.F. Oliveira, C.N. Souto, P.C. Martins, I.C. Di Castro, A.G. Mascarenhas. Mycotoxins in broiler production. Revista de Ciências Agroveterinárias. 2018. Vol.17. No.2. P.292-299. https://doi.org/10.5965/223811711722018292

[3] J. Fink-Gremmels. Mycotoxins in roughage and succulent feed. ed. D. Diaz. Mycotoxins and mycotoxicoses. Moscow. 2006. P.157-178. (russian)

[4] S. Schaarschmidt, C. Fauhl-Hassek. Fate of Mycotoxins During the Processing of Wheat for Human Consumption. Compr. Rev. Food Sci. Food Saf. 2018. Vol.17. P.556-593.

[5] B. Arce-López, E. Lizarraga, A. Vettorazzi, E. González-Peñas. Human Biomonitoring of Mycotoxins in Blood, Plasma and Serum in Recent Years: A Review. Toxins. 2020. Vol.12. P.147. https://doi.org/10.3390/toxins 12030147

[6] V. Antipov, V. Vasiliev. System of measures for the prevention of mycotoxicosis in animals and birds. Veterinary Medicine of Farm Animals. 2009. No.9. P.18-21. (russian)

[7] A. Brylin. Mycotoxicosis of birds. Veterinary Medicine of Farm Animals. 2009. No.9. P.22-24. (russian)

[8] Y.M. Abdulrazzaq, N. Osman, A. Ibrahim. Fetal exposure to aflatoxins in the United Arab Emirates. Ann. Trop. Paediatr. 2002. Vol.22. P.3-9.

[9] P. Vila-Donat, S. Marín, V. Sanchis, \& A.J. Ramos. A review of the mycotoxin adsorbing agents, with an emphasis on their multi-binding capacity, for animal feed decontamination. Food and Chemical

Toxicology. 2018. Vol.114. P.246-259. https://doi.org/10.1016/j.fct.2018.02.044 
[10] E.Y. Tarasova, L.E. Matrosova, S.A. Tanaseva, N.N. Mishina, R.M. Potekhina, O.K. Ermolaeva, S.Yu. Smolentsev, A.M. Tremasova, I.R. Kadikov, V.I. Egorov, R.M. Aslanov, E.I. Semenov Protective effect of adsorbent complex on morphofunctional state of liver during chiken polymycotoxicosis. Systematic reviews in pharmacy. 2020. Vol.11. No.11. P.264-268

[11] TR CU 015/2011 Technical Regulation of the Customs Union on Safety of Grain (as amended on September 15, 2017): approved by the Customs Union Decision No. 874 of 9 December 2011. Available at: http://docs.cntd. ru/document/902320395. (russian)

[12] TR CU 021/2011 Technical Regulations of the Customs Union On Food Safety(as amended on August 8, 2019): approved by the Customs Union Decision No. 880 of 9 December 2011. Available at: http://docs.cntd.ru/document/902320560 (russian)

[13] Guidelines for the detection, identification and determination of the content of deoxynivalenol (vomitoxin) and zearalenone in grain and grain products No.5177-90.1990. 14p. https://files.stroyinf.ru/Index2/1/4293828/4293828870.htm

[14] G.P. Kononenko, A.A. Burkin, E.V. Zotova Mycotoxicological monitoring. Part 2. Grain of wheat, barley, oats, corn. Veterinary Medicine Today. 2020. Vol.2. P.139-145. (russian)

[15] I.N. Shtyrov, N.N. Mishina, A.R. Valiev, E.Yu. Tarasova, E.I Semyonov. Development of an enzyme immunoassay protocol for the indication of T-2 toxin. Veterinarian. 2020. No.3. P.67-72. (russian)

[16] N.N. Mishina, E.I. Semyonov, A.F. Khasiyatullin, R.M. Potekhina, L.E. Matrosova, Z.A. Kanarskaya The effectiveness of enterosorbents of various natures in pigs polymycotoxicosis. Veterinary. $\mathbf{2 0 2 0 .}$ No.11. P.49-53. (russian) 